\title{
A localized PCR inhibitor in a porcelain crab suggests a protective role
}

A number of polymerase chain reaction (PCR) inhibitors have been identified from biological and environmental samples. By and large, such substances are treated as random nuisances and contaminants with alternate functions; their inhibitory effects on DNA replication being a coincidental property of their molecular structure. Here, we demonstrate the presence of a localized PCR inhibitor in the foregut of the porcelain crab Petrolisthes rufescens (Anomura: Porcellanidae) from the Red Sea. The inhibitor precluded amplification of $28 \mathrm{~s}, 16 \mathrm{~s}$ and $18 \mathrm{~s}$ gene sequences effectively but lost activity at $10^{-2}$ dilutions from initial concentration. Heat treatment was ineffective in arresting inhibition and spectrophotometric techniques suggested that the inhibitor was not a melanin-type compound. The compound was not detected from midgut, hindgut, or gills of the crab. Activity of the inhibitor was precluded when samples were treated with suspensions from the midgut, suggesting that enzymatic degradation of the inhibitor likely happens at that part of the gut. As many microbial pathogens invade their hosts via ingestion, we suggest the presence of the localized inhibitor could carry a defensive or immunological role for $P$. rufescens. The identity of the inhibitory molecule remains unknown. 
1 Title: A localized PCR inhibitor in a porcelain crab suggests a

2 protective role

3 Authors: Mahmoud A. El-Maklizi ${ }^{1}$, Amged Ouf ${ }^{1,2}$, Ari Ferreira ${ }^{2}$, Shahyn Hedar ${ }^{1}$,

4 Edwin Cruz-Rivera ${ }^{3 *}$

$5 \quad$ Biology Department, The American University in Cairo, P.O. Box 74, New Cairo

$6 \quad 11835$, Egypt

$7 \quad$ Biotechnology Program, The American University in Cairo, P.O. Box 74, New

8 Cairo 11835, Egypt

$9{ }^{3}$ Biological Sciences Program, Asian University for Women, 20/A M.M. Ali Road,

10 Chittagong, Bangladesh

11 *Corresponding author: edwin.rivera@auw.edu.bd 
Introduction

Polymerase chain reaction (PCR) is a powerful, rapid method for the diagnosis of microbial infections and genetic diseases, the detection microorganisms in environmental and food samples, forensics, and the amplification of DNA sequences for phylogenetic and ecological studies (McCartney, 2002; Rådström et al., 2004; Maurer 2011; Alaeddini 2012). Application of this tool to environmental and biological samples is often hampered by the presence of unknown inhibitors that block one or more of the steps yielding DNA amplification, and a variety of organic and inorganic inhibitors have been detected or isolated (Wilson, 1997; Rådström et al., 2004; Schneider, Enkerli \& Widmer, 2009; Maurer, 2011; Alaeddini, 2012; Schrader et al., 2012). Inhibitors can affect any step of PCR and normally act by reducing or arresting cell lysis required to extract DNA, by degrading nucleic acids, by binding to, and blocking capture of, nucleic acids, or by inhibiting the action of polymerases in amplifying target DNA (Wilson, 1997; Alaeddini, 2012; Schrader et al., 2012). The different mechanisms are a reflection of the diversity of chemical structures of inhibitors, many of which are widespread in nature, including phenolic compounds and humic acids, carbohydrates like glycogen, fats, and various proteins (Wilson, 1997; Rådström et al., 2004; Maurer, 2011; Alaeddini, 2012; Schrader et al., 2012). In the case of studies with animals, skin, muscle and blood components, including pigments (e.g., hemoglobin, melanin) are known to block PCR (Yoshii et al., 1993; Akane et al., 1994; Belec et al., 1998; Eckhart et al., 2000). For such cases sample preparation often requires dilution of the samples containing the inhibitor, pretreatment of extracted DNA aliquots with columns of specific molecular affinities to bind inhibitors, immunocapture of cells, the use of two-phase aqueous systems to separate cells or DNA from inhibitors, the addition of substances that precipitate the suspected inhibitor, or the alternative use of different polymerases with varying sensitivities to inhibition (Rådström et al., 2004; Schneider, Enkerli \& Widmer, 2009; Maurer, 2011; Alaeddini, 2012; Schrader et al., 2012). 
vast majority of molecular studies finding PCR inhibitors have largely considered such

substances as coincidental contaminants in the samples (see above reviews). Given that many of

the inhibitors isolated to date have other known biological functions, interference of PCR by these substances is considered incidental. This has resulted in an overall lack of work aimed at understanding the potential role of such inhibitors in controlling the replication of DNA foreign

\section{Materials and Methods}

Petrolisthes rufescens (Heller, 1861) were collected at low tide from underneath rocks in the Ain Sukhna intertidal, Gulf of Suez, Egypt $\left(29^{\circ} 57^{\prime} \mathrm{N} 32^{\circ} 32^{\prime} \mathrm{E}\right)$. Individuals were kept alive in 
plastic tubs with fresh seawater and transported to The American University in Cairo, where they were individually placed in plastic bags and frozen at $-20^{\circ} \mathrm{C}$. Animals used were mature adults. Despite its broad geographic distribution and potentially dense populations (e.g., in our collection sites, see Supplementary Information), very little is known about the basic biology and ecology of this species (Ahmed \& Mustaquim, 1974; Yaqoob, 1974; Paul, Sankolli \& Shenoy, 1993), but it is a filter feeder that traps floating particles by extending its plumose third maxillipeds like other porcelain crabs (Achituv \& Pedrotti, 1999; Valdivia \& Stotz, 2006; Riisgård \& Larsen, 2010). We have maintained specimens alive in recirculated seawater by feeding them on a mixture of live Artemia salina nauplii and finely-ground fish food flakes for over seven months.

Extraction of DNA was performed on frozen crabs $(\mathrm{N}=6$ for our preliminary extractions to quantify DNA yield [Table 1] and $\mathrm{N}=3$ for all experiments after). These were dissected to separate foregut, midgut, hindgut, muscle, and gills under a dissecting microscope, as necessary (see below). During dissection, animals were placed on a Petri dish kept cold above a layer of ice. DNA from each tissue was extracted using the DNEasy tissue extraction kit (Qiagen cat \# 69504) and the DNEasy spin column protocol. Each tissue sample was placed in a $1.5 \mathrm{ml}$ microcentrifuge tube and ground under $180 \mu 1$ of Buffer ATL, before adding $40 \mu 1$ of proteinase $\mathrm{K}$ and incubating at $56^{\circ} \mathrm{C}$ for 1 hour. Proteinase $\mathrm{K}$ was added at twice the specified concentration (unless otherwise indicated below) because we expected the digestive system environment to be high in proteins that could potentially inhibit PCR. Samples were periodically vortexed during digestion, and then finally for 15 minutes, before adding $200 \mu 1$ of Buffer AL and $200 \mu 1$ of ethanol, and vortexing again. DNA was purified by centrifuging serially in a DNeasy Mini spin column in three one-minute steps, including transfer to two purification buffers, as per manufacturer specifications. All transfer procedures were performed inside a sterile hood. Separate amplifications were periodically performed (without crab or fish tissues) to assess contamination of the buffers and sterile water used in the procedures. 
was extracted using the same protocols and served as positive control in various experiments as explained below. Henceforth, the use of the word "extract" will refer to aliquots resulting from DNA extraction procedures. A NanoDrop 3300 fluorospectrometer was used to quantify DNA extracted using the Quant-iT PicoGreen dsDNA assay kit (Life technologies cat\# P11496). As per manufacturer specifications, this instrument and technique can detect DNA concentrations down to $0.001 \mathrm{ng} / \mu \mathrm{l}$. To assess the efficiency of our DNA extraction protocols, preliminary quantification was performed on parts from 6 randomly selected crabs and on the fish DNA used as control. Two serial dilutions per sample were done, $10^{-1}$ and $10^{-2}$, and an equal volume of the dye was added to each dilution before measuring absorbance 530. We also used NanoDrop fluorospectrometry throughout the study to standardize the amount of DNA in our PCR reactions to 2ng of extracted crab DNA and 2ng of control fish DNA. Early experiments (e.g., Fig. 1) showed the best amplification of fish DNA in reactions using this amount (see below). This is also consistent with other studies using 2 ng of DNA per 20-25 $\mu 1$ PCR reaction, although amplification can be observed at much lower concentrations (Andrade et al. 2012; Jin et al., 2012; Bernal-Martínez et al., 2013; Batmalle et al., 2014; Okeke et al., 2014)

To assess the presence and distribution of the inhibitor various PCR-based experiments were designed. All PCR reactions were developed on 1.0-1.7\% agarose gels stained with ethidium bromide and the intensity of the bands obtained was observed under UV light in an ImageQuant 300 (General Electric) gel imaging system. PCR conditions for each primer used are provided in the Supplementary Materials. In the first experiment, we assessed the sensitivity of our protocols and the possibility that the previously observed lack of DNA amplification in the foregut could be due to either too high or too low concentrations of DNA, both of which can lead to false negatives in PCR (Wilson, 1997; Alaeddini, 2012). Foregut extracts from individual crabs $(\mathrm{N}=3)$ were diluted serially by decreasing the amount of extracted DNA added to the PCR 
reaction in a total volume of $20 \mu 1$ per reaction. In this initial exploration, NanoDrop readings showed extracted DNA amounts of 18.7, 4.1, and 0.93ng in undiluted crab foreguts (FG1, FG2, and FG3, respectively, Fig. 1). These amounts were twice serially diluted in half for each crab and the three concentrations were then used in PCR reactions. Thus this experiment tested amplification using foregut concentrations of ca. 19 (FG1) to $0.25 \mathrm{ng}$ (0.25 of undiluted FG3) per reaction. As controls, five dilutions of fish DNA (5, 4, 3, 2 and 1ng per PCR reaction) were simultaneously run. Reactions were amplified using the 28 s primers OI (5 'GTCTTTGCGAAGAAGAACA-3 ') and DIB (5' -AGCGGAGGAAAAGAAACTAAC-3') described in Morrison et al. (2002).

We directly assessed the inhibitory activity of $P$. rufescens foreguts $(\mathrm{N}=3)$ using a fixed amount of foregut DNA extract (2ng) and control fish DNA (2ng) added to the reactions. Using the same primers for amplification described above (28s), PCR reactions were run along a control containing 2ng of fish DNA in the reaction, but no extracted crab foregut (positive control) and a negative control lacking any DNA. Prior assays showed positive amplification at even higher amounts of DNA than 4ng (Fig. 1). Thus, failure to obtain amplified fish 28s DNA in the presence of crab foregut extracts would indicate inhibition or disruption of PCR compared to a successfully amplified 28s band in the control containing only fish DNA. For this experiment, crab extracts were diluted twice (as in the previous experiment), resulting in reactions with 2,1 , and $0.5 \mathrm{ng}$ of foregut DNA.

To assess whether the inhibitor was systemic in the crabs, amplification was further performed on DNA extracted from various parts of the crabs (foregut, midgut, hindgut, and gills). For this experiment, we used universal bacterial primers and, therefore, the experiment also provided indirect information on the presence of microbes in the gut and other organs of $P$. rufescens. Thus the purpose of the experiment was twofold. First, it determined if inhibition was localized in the foregut of the crab. Second, using bacterial primers also assessed if inhibition 
was related to PCR specifically and not to difficulties amplifying nuclear genes such as $28 \mathrm{~s}$. The universal primers (Fierer et al., 2007) Bac8f (5'-AGAGTTTGATCCTGGCTCAG-3') and Univ529r (5'-ACCGCGGCKGCTGGC-3’) were used on samples (N=3) of: 1) midguts, hindguts, and gills pooled per crab and 2) foreguts, midguts, hindguts and gills pooled per crab. Samples were adjusted so that a total of 2 ng of DNA (based on NanoDrop readings) were used in each PCR reaction: 1ng of DNA from the foregut mixed with a total of 1ng of DNA from midgut, hindgut and gills together. A negative control (all PCR components except crab extract) was run simultaneously to assess potential microbial contamination of reagents during the experimental process.

The limits of activity of the inhibitor were assessed by progressively reducing the amount of foregut extract in PCR reactions containing 2ng aliquots of fish DNA. For this, the amount of crab foregut extract was sequentially diluted in multiples of 10 from initial (2ng) concentrations $\left(10^{-1}, 10^{-2}, 10^{-3}\right.$, and $\left.10^{-4}\right)$ and then added to the PCR reactions, which were then amplified using the 18 s primers 18E-F (5'-CTGGTTGATCCTGCCAGT-3') and 18sR3 (5'TAATGATCCTTCCGCAGGTT-3') (Kim and Abele, 1990). Thus, fish DNA was amplified in the presence of undiluted foregut $(\mathrm{N}=3)$ aliquots, plus four serial dilutions of these same aliquots, along with two positive controls (2ng of fish DNA added alone) and a negative control (all PCR components except DNA from crabs or fish) for assessing contamination (using yet a different set of primers to assess generality of the inhibitor).

If the inhibitor served a functional role in the foregut, and its activity was generalized for DNA replication, it was expected that regulation of some sort would keep the compound from affecting other parts of the digestive tract, where it could inhibit other potentially beneficial microbes or cells. To test for this, two experiments were performed by comparing the inhibition of PCR by foregut extracts versus that of foreguts mixed with midgut suspensions. Our hypothesis was that enzymatic degradation (or any other type of neutralization) of the inhibitor 
occurred in the midgut, the contiguous digestive chamber of the crab. Because our interest was to account for enzyme activity, we did not add proteinase $\mathrm{K}$ to the samples. Other protocols were kept the same. In the first experiment, undiluted extracts of foreguts (2ng) were mixed with 2 ng control fish DNA. These were compared to samples from the same crabs in which foreguts and midguts were mixed in equal amounts before adding the fish DNA. All reactions were processed by using the $18 \mathrm{~s}$ primers previously described. Foreguts and midguts were homogenized in $100 \mu 1$ of Ultrapure, DNase and RNase free water (Invitrogen inc.). The foreguts were extracted as above.

The follow-up experiment aimed at establishing the minimum activity of the midgut suspensions that would arrest the activity of the inhibitor. This experiment followed the protocols above, but after the extraction, $50 \mu 1$ of the foreguts were divided into five equal portions $(10 \mu 1$ each). To each portion an equal volume of either the midgut initial suspension from that same crab or one of its dilutions $\left(10^{-1}, 10^{-2}, 10^{-3}, 10^{-4}\right)$ was added. The mixtures were incubated at $42^{\circ} \mathrm{C}$ for two hours on a shaking thermoblock. This temperature was chosen to represent a potential extreme observed in areas of Egypt during summertime. Crabs often spend several hours above water when the tide recedes, where they were are surrounded by tan to dark rocks and gravel (see Supplementary Information). After the incubation period, another round of extraction was done on the mixtures. The extracted mixtures were then used in the 18s PCR. Each PCR reaction contained $2 \mu 1$ of the mixture plus $3 \mu 1$ of fish DNA. In total, each mixture of foregut and midgut from the same crab $(\mathrm{N}=3)$ had five PCR reactions (15 PCR reactions in total). For this one and the previous assay samples were normalized using masses because the midguts were not extracted, but rather macerated in water and suspended in buffer, keeping us from normalizing using NanoDrop readings.

Because the identity of the inhibitor was unknown, we assessed qualitatively whether the molecule was a protein with a secondary, tertiary or quaternary structure. Three crab foreguts 
were individually heated in $\mathrm{AE}$ buffer using a thermoblock at $99^{\circ} \mathrm{C}$ for one hour. The boiled foreguts were then extracted using the explained procedures and 2 ng of each product was added to 2 ng of fish DNA. PCR was then performed using 18 s primers as previously. By comparing simultaneously the three mixtures of pre-heated foreguts with fish DNA against a sample of the same fish DNA alone, we determined if heating degraded the inhibitory molecule, as would be expected from a complex protein (but see Abu AL-Soud, Jönsson \& Rådström, 2000).

The possibility that the inhibitor was a melanin-type of pigment was also tested. Melanins occur in crustaceans and other invertebrates (Söderhäll, 1982; Bandaranayake, 2006; Vázquez et al., 2009; Dubey \& Roulin, 2014), and are known to interfere with PCR (Alaeddini, 2012; Schrader et al., 2012). We assessed the possibility that the inhibitor was a melanin-related compound using the spectrophotometric approach developed by Dörrie et al. (2006). Six treatment groups: crab foregut, midgut, hindgut, gills, and muscle, and fish muscle $(\mathrm{N}=4)$ were extracted with the same protocols previously described and tested. A dilution of $20^{-1}$ for each sample using TE buffer was made in a total volume of $400 \mu 1$. The absorbance of each sample at $320 \mathrm{~nm}$ was measured using a UV spectrophotometer. The measurement was repeated twice for each sample, using $196 \mu$ l each time and the two readings were subsequently averaged. The absorbances of the six groups were compared using one-way ANOVA. While this method does not quantify absolute melanin content in the absence of a melanin standard, or non-soluble melanin present in the tissues, it does provide reliable information on relative amount of melanin dissolved among samples (Dörrie et al., 2006; Sánchez-Rodríguez et al., 2008). A high absorbance of the foreguts in relation to other tissues would suggest the presence of either naturally-occurring melanins or a similar compound leached from tissues nearby the mouth parts.

\section{Results}

Although variation in extracted yield was high, all samples showed non-zero readings for 
DNA (Table 1). The concentrations ranged from a minimum of 0.003 (in one midgut) $\mathrm{ng} / \mu \mathrm{l}$ to a maximum of $9.53 \mathrm{ng} / \mu 1$ (also in a midgut). Extracted DNA from the foreguts ranged from a minimum of $0.156 \mathrm{ng} / \mu \mathrm{l}$ to a maximum of $3.123 \mathrm{ng} / \mu \mathrm{l}$. For comparison, the fish muscle sample used as control in the first dilution experiment yielded $1.141 \mathrm{ng} / \mu 1$. On average the lowest amounts of DNA were obtained from the hindgut and foregut (Table 1). Despite yielding comparable amounts of DNA to control fish DNA concentrations, foreguts did not amplify when 28s primers were used, regardless of the amount of aliquot added to the PCR reactions (Fig. 1). In contrast, all five concentrations of control fish DNA showed amplified bands, with the best resolution when $2 \mu$ l of aliquot (ca. 2 ng) were added to the PCR reactions. Given the patterns of strong positive amplification of fish DNA in this experiment, 2ng of fish DNA aliquots were used as controls to test for PCR inhibition in subsequent assays. Foregut aliquots ranging from 6-2 $\mu$ l from different individual crabs arrested PCR in all cases (Fig. 2). In the absence of any foregut extract, 28s primers amplified fish DNA strongly and the negative control showed this amplification could not be explained by contamination of the mix (Fig. 2). This inhibition was seen when using bacterial 16s primers as well. When midgut, hindgut and gills from three crabs were extracted together and amplified using the bacterial primers, clear bands around $500 \mathrm{bp}$ were observed (Fig. 3). In contrast, when the same mixtures from the same individuals also contained aliquots from the foregut, no bands were observed. A negative control showed no amplification either (Fig. 3). The inhibitor was effective up to one tenth of its concentration in the aliquots as shown in an experiment using 18 s primers (Fig. 4). Further dilutions produced clear amplified product bands in the gels on the same expected positions as those from the positive controls (only fish DNA). No contamination of the mix (negative control) was detected (Fig. 4).

Amplification of control DNA with 18s in the presence of foregut extracts was possible if midgut suspensions were present in the mix, thus suggesting regulation of the inhibitor in the 
midgut (Fig. 5). The effect of the midgut component (or components) counteracting the activity of the inhibitor was detected even at $10^{-4}$ dilutions of the original midgut aliquot (Fig. 6). For the sample FG3+MG3 $\left(10^{-4}\right)$ there was only a faint band, suggesting that the dilution of the midgut was approaching the limit of activity against the inhibitor. For these two experiments, both positive and negative controls showed the expected patterns (Figs. 5 and 6).

The inhibitor was heat stable as shown by an experiment in which foregut extracts from three individuals crabs were heated for an hour at $99^{\circ} \mathrm{C}$ before adding them to the PCR reactions. The addition of these boiled extracts to fish DNA blocked amplification with 18s, while fish DNA without any foregut extract added, amplified at the expected band size (Fig. 7). This suggests that the inhibitor is not a protein with a complex structure that would undergo denaturation. The inhibitor also did not react as expected from a melanin-like compound (Dörrie et al., 2006). When extracts from all three main sections of the crab gut, gills, crab muscle and fish muscle were spectrophotometrically evaluated, no significant differences in absorbance were observed (Fig. 8). In fact, despite sometimes large variance, absorbance for most samples ranged from 0-0.05 and was not statistically different than zero ( $\mathrm{P} \geq 0.219$, Mann-Whitney U tests). Oneway ANOVA showed no significant difference between any of the six treatment groups in terms of potential melanin content $(\mathrm{P}=0.284$; Fig. 7$)$.

\section{Discussion}

A compartmentalized PCR inhibitor was present in the foregut, but not other parts, of the porcelain crab Petrolisthes rufescens. This was clear from the absence of any amplified DNA bands at the expected sizes using $28 \mathrm{~s}, 16 \mathrm{~s}$ or $18 \mathrm{~s}$ primers when foregut extracts were present. The inhibition of amplification of both nuclear (28s and 18s) and microbial genes (bacterial 16s) suggests that the activity of the inhibitor is general and potentially effective against both eukaryotes and prokaryotes. Excess or critically low amounts of DNA in the samples did not 
explain inhibition of PCR (Wilson, 1997; McBeath et al., 2006; Pan et al., 2008; Alaeddini, 2012). Firstly, NanoDrop measurements showed that the amounts of DNA in extracted foregut samples compared to those extracted from other crab tissues and from fish (Table 1). Second, all dilutions of all samples of foreguts in the first experiment (which evidently contained DNA) failed to amplify using 28s primers, whereas the five dilutions of fish DNA amplified well (Fig 1). Dilution has been successful in reducing or eliminating the effects of inhibitors in PCR either by reducing the amount of the inhibitor or of the DNA template (Wiedbrauk, Werner \& Drevon, 1995; Mättö et al., 1998; McBeath et al., 2006; Pan et al., 2008; Alaeddini, 2012). The fact that DNA was extracted from foreguts at comparable concentrations to those of samples which amplified suggests a highly active or concentrated inhibitor in P. rufescens. That the inhibitor was found only in the foregut (or at least found in effective concentrations to arrest PCR) was confirmed by amplifying bacterial 16s rRNA genes from midgut and hindgut, along with gills. Clear amplification only happened when foreguts were absent from the mixture (Fig. 3).

When dilutions were used to assess the lower limits of activity of the inhibitor, inhibition was still observed at one order of magnitude below the initial extracted amount (Fig. 4).

Although we do not show these data, similar results were observed by decreasing progressively in half the amount of aliquot used in the reactions and amplifying with 28 s primers (see Supplementary Information). In that experiment, when fish 28s DNA was amplified in the presence of crab foregut extracts all the three dilutions of the foreguts inhibited amplification, whereas the control, lacking foregut extracts, amplified. The mass of extracted foreguts for the dilution experiment above was known (26-42 mg). However, the foregut of crustaceans is lined with a cuticle that is largely comprised of chitin (Brunet, Arnaud \& Mazza 1994; McGaw \& Curtis, 2012; Watling, 2013). Thus, the amount of actual tissue that could secrete and/or store the inhibitory molecule was unknown. Experiments using real time-QPCR (Schneider, Enkerli \& Widmer, 2009) or internal positive controls for PCR (Hartman, Coyne, \& Norwood, 2005) could 
provide better resolution for the activity of the inhibitor and its effective concentration. The conclusive determination of the precise inhibitory molecule and its concentration, however, will require chemical microtechniques that will allow elucidation of components in very small tissue samples as to reduce collection impacts on porcelain crab populations.

While the identity of the molecule responsible for the observed results remains unknown, the inhibitor did not appear to be a protein or peptide. Neither increasing proteinase $\mathrm{K}$ added to the samples during extraction (see Methods), or heating foregut samples at $99{ }^{\circ} \mathrm{C}$ for $1 \mathrm{hr}$ before amplifying by PCR, reduced the inhibitory activity (Fig. 7). Medical studies aimed at detecting pathogens in saliva and ocular fluids have found similar results (Ochert et al., 1994; Wiedbrauk, Werner \& Drevon, 1995; Mättö et al., 1998). Ochert et al. (1994) concluded that PCR inhibitors in their saliva samples were likely carbohydrates, based on the addition of proteinase K, extraction in phenol-chloroform, treatment with ion-exchange resins, and boiling of the samples. Our results similarly suggest a carbohydrate inhibitor, although it is unknown if small glycopeptides or other mixed-origin molecules can survive proteinase K digestion. It should also be noted that, in one case, PCR inhibition by a protein (immunoglobulin G) has been shown to increase with temperature (Abu AL-Soud, Jönsson \& Rådström, 2000).

We can, however, dismiss the occurrence of another group of known PCR inhibitors: the melanins (Yoshii et al. 1993; Eckhart et al., 2000; Opel, Chung \& McCord, 2009). These compounds are abundantly found in invertebrates, including crustaceans (Bandaranayake, 2006; Dubey \& Roulin, 2014), where they are associated with processes of wound repair and immune response (Söderhäll, 1982; Sritunyalucksana \& Söderhäll, 2000; Vázquez et al., 2009; Dubey \& Roulin, 2014). The mechanisms of PCR inhibition by melanins have been explicitly studied. Theseinclude binding directly to polymerases (Eckhart et al., 2000) or reducing the amount of template available for amplification by binding to specific DNA sequences (Opel, Chung \& McCord, 2009; Geng et al., 2010); longer amplicons may be more sensitive to the effects of 
melanin than short ones (Opel, Chung \& McCord, 2009). Using a spectrophotometric technique (Dörrie et al., 2006) we compared samples of P. rufescens foregut, midgut, hindgut, gills, and muscle, and fish muscle (Fig. 8). No significant differences in absorbance were found among tissues, suggesting that the inhibitor was not a melanin-like compound localized in the foregut. While we did not attempt to quantify the potential amounts of melanin-like compounds in the tissues (using a purified standard), absorbances were close to zero and the most variable signal was found in the crab muscle, from which we have readily amplified bacterial sequences in other experiments (see Supplementary Information).

A functional molecule is expected to be regulated by the organism containing it.

Preliminary observations showed that microbial sequences could be recovered from other parts of the digestive tract of $P$. rufescens. Therefore, we hypothesized that regulation of the inhibitor would occur in the midgut. This was confirmed when control fish DNA was amplified successfully in the presence of foregut extracts only if they were mixed with midgut suspensions. Two lines of evidence suggest that the regulatory molecule is an enzyme or at least a protein in the midgut. First, midgut suspensions did not counteract the inhibitor when proteinase K was added to the PCR mix (Fig 3). In contrast, when proteinase K was absent, amplification of DNA was possible even at $10^{-4}$ dilutions of midgut suspensions (Fig. 6). Second, the midgut contains secretions from the hepatopancreas, a multiple-function digestive and absorptive organ that produces a variety of digestive enzymes (Brunet, Arnaud \& Mazza, 1994; McGaw \& Curtis, 2012; Watling, 2013). The secretory ability of the hindgut is mainly restricted to producing mucus to facilitate the expulsion of feces. Some ion uptake may also occur, but a role in enzymatic degradation of the inhibitor is unlikely.

The location of the inhibitor suggests a potential role in immunity and pathogen control for $P$. rufescens. It may also serve as a bottleneck for the control of gut flora by selecting for specific microbes to colonize the gut. The foregut is among the first internal compartments in 
contact with ingested water and particles from the outside environment. Hence, it is a prime route through which pathogens can gain entrance (Small \& Pagenkopp, 2011). Being a filter feeder, $P$. rufescens may have some ability to control for size of ingested particles, but it is unlikely to control the nature of microbes attached to them. The inhibitor could serve as a broad action barrier to reduce pathogen invasion. DNA polymerization is fundamental for cell proliferation and some natural antibiotic compounds are known to provide immunity to plants, invertebrates and vertebrates (Zasloff, 2002; Brogden et al., 2003; Tincu \& Taylor, 2004; OteroGonzález et al., 2010; Brandenburg et al., 2012) by inhibiting DNA replication, among other mechanisms (Boman, Agerberth \& Boman, 1993; Brogden, 2005; Brandenburg et al., 2012). Most of these compounds are small peptides, which could potentially survive extraction methods such as ours. Although the majority of these have been isolated from hemolyph and hemocytes, some are produced in the buccal cavity or digestive tract of the organisms, including humans (Boman, Agerberth \& Boman, 1993; Gorr, 2009; Brandenburg et al., 2012). It is unclear how the crab avoids the negative effects of the inhibitor within its foregut tissues. One possibility is that the cuticle lining the foregut (Brunet, Arnaud \& Mazza, 1994; McGaw \& Curtis, 2012; Watling, 2013), serves as a barrier preventing the widespread penetration of the inhibitor into the crab cells. Exclusion at the level of the cell membrane could also explain this. Another relevant question is how gut microbes in the midgut and hindgut circumvent the inhibitor. Clearly, chemical isolation of the inhibitor (and its counteracting molecule in the midgut), and definitive proof of the foregut inhibitor effects in vivo are needed before its natural role can be conclusively determined.

Our findings have implications for the design of studies using molecular tools to detect small organisms in environmental samples, and for those assessing gut microbial diversity in crustaceans and other animals. The potential to obtain false negatives from molecular probes is higher for small organisms in which tissues or organs cannot be clearly separated and are, 
therefore, processed as whole animals. Inhibitors can obscure the detection of larval crustaceans and gastropods (Vadopalas et al. 2006, Jensen et al., 2012), as well as parasitic copepods (McBeath et al., 2006), from plankton samples. Other inhibitors hamper PCR on the resting eggs of fairy shrimp (Moorad et al. 1997), the eyes of bees (Boncristiani et al. 2011) and when detecting pathogens in shrimp tissues (Wang et al. 1996). While an array of inhibitors has been studied from biomedical studies, food microbiology, and forensics (Wilson, 1997; Maurer, 2011; Alaeddini, 2012; Schrader et al., 2012), we suspect such information from other fields is often relegated to unpublished observations about experiments that did not work among scientist notes. Clearly, there is a practical relevance to the study of inhibitors in order to create protocols for optimizing PCR (Wilson, 1997; Rådström et al., 2004; Alaeddini, 2012), but such inhibitors may also provide leads into drug discovery. Polymerase inhibitors have been, and continue to be, studied as potential agents against microbial pathogens and cancer, for which arresting cell proliferation is a fundamental step in treatment (Liu-Young \& Kozal, 2008; Javle \& Curtin, 2011; Gane et al., 2013). To date, however, the ecological and evolutionary relevance of these inhibitors has been largely overlooked.

\section{Acknowledgements}

This research was produced in partial fulfillment of an undergraduate senior thesis from the Biology Department of The American University in Cairo by the first author. Funding was provided by a Faculty Research Grant from the American University in Cairo to E. Cruz-Rivera, and by the King Abdullah University for Science and Technology Global Collaborative Partners (GCR) program, which supported A. Ferreira and A. Ouf. We gratefully acknowledge Mohie ElDin Sherif and Tamer Hafez for their help collecting specimens and Hamza El-Dorry for suggestions and the use of equipment. We also thank Arthur Bos for providing the fish for DNA extraction. Comments by Pietro Gatti-Lafranconi, Michael Sweet and Christina Eichstaedt 
greatly improved this manuscript.

\section{References}

Abu Al-Soud, W., Jönsson, L. J., and Rådström, P. 2000. Identification and characterization of immunoglobulin $\mathrm{G}$ in blood as a major inhibitor of diagnostic PCR. Journal of Clinical Microbiology 38:345-350.

Achituv Y, Pedrotti ML. 1999. Costs and gains of porcelain crab suspension feeding in different flow conditions. Marine Ecology Progress Series 184:161-169.

Ahmed M, Mustaquim J. 1974. Population structure of four species of porcellanid crabs (Decapoda: Anomura) occurring on the coast of Karachi. Marine Biology, 26:173-182.

Akane A, Matsubara K, Nakamura H, Takahashi S, Kimura K. 1994. Identification of the heme compound copurified with deoxyribonucleic acid (DNA) from bloodstains, a major inhibitor of polymerase chain reaction (PCR) amplification. Journal of Forensic Sciences, 39:362-372.

Alaeddini R. 2012. Forensic implications of PCR inhibition - a review. Forensic Science International: Genetics 6:297-305.

Andrade LL, Leite DCA, Ferreira EM, Ferreira LQ, Paula GR, Maguire MJ, Hubert CRJ, Peixoto RS, Domingues RMCP, Rosado AS. 2012. Microbial diversity and anaerobic hydrocarbon degradation potential in an oil-contaminated mangrove sediment. BMC Microbiology 12: 186.

Bandaranayake WM. 2006. The nature and role of pigments of marine invertebrates. Natural Product Reports 23:223-255.

Batmalle CS, Chiang HI, Zhang K, Lomas MW, Martiny AC. 2014. Development and bias assessment of a method for targeted metagenomic sequencing of marine cyanobacteria. Applied and Environmental Microbiology 80:1116-1125. 
Belec L, Authier J, Eliezer-Vanerot MC, Piedouillet C, Mohamed AS, Gherardi RK. 1998. Myoglobin as a polymerase chain reaction (PCR) inhibitor: a limitation for PCR from skeletal muscle tissue avoided by the use of Thermus thermophilus polymerase. Muscle Nerve 21:1064-1067.

Bernal-Martínez L, Buitrago MJ, Castelli MV, Rodriguez-Tudela JL, Cuenca-Estrella M. 2013. Development of a single tube multiplex real-time PCR to detect the most clinically relevant Mucormycetes species. Clinical Microbiology and Infection 19:E1-E7.

Boman HG, Agerberth B, Boman A. 1993. Mechanisms of action on Escherichia coli of cecropin P1 and PR-39, two antibacterial peptides from pig intestine. Infection and Immunity 61:2978-2984.

Boncristiani H, Li J, Evans JD, Pettis J, Chen Y. 2011. Scientific note on PCR inhibitors in the compound eyes of honey bees, Apis mellifera. Apidologie 42:457-460.

Brandenburg LO, Merres J, Albrecht LJ, Varoga D, Pufe T. 2012. Antimicrobial peptides: multifunctional drugs for different applications. Polymers 4:539-560.

Brogden KA. 2005. Antimicrobial peptides: pore formers or metabolic inhibitors in bacteria? Nature Reviews Microbiology 3:238-250.

Brogden KA, Ackermann M, McCray Jr PB, Tack BF. 2003. Antimicrobial peptides in animals and their role in host defences. International Journal of Antimicrobial Agents 22:465-478.

Brunet M, Arnaud J, Mazza J. 1994. Gut structure and digestive cellular processes in marine Crustacea. Oceanography and Marine Biology: An Annual Review 32:335-367.

Dörrie J, Wellner V, Kämpgen E, Schuler G, Schaft N. 2006. An improved method for RNA isolation and removal of melanin contamination from melanoma tissue: Implications for tumor antigen detection and amplification. Journal of Immunological Methods 313:119128.

Dubey S, Roulin A. 2014. Evolutionary and biomedical consequences of internal melanins. 
Pigment Cell and Melanoma Research 27:327-338.

Fierer N, Breitbart M, Nulton J, Salamon P, Lozupone C, Jones R, Robeson M, Edwards RA, Felts B, Rayhawk S, Knight R, Rohwer F, Jackson RB. 2007. Metagenomic and smallsubunit rRNA analyses reveal the genetic diversity of bacteria, archaea, fungi, and viruses in soil. Applied and Environmental Microbiology 73:7059-7066.

Eckhart, L., Bach, J., Ban, J., \& Tschachler, E. (2000). Melanin binds reversibly to thermostable DNA polymerase and inhibits its activity. Biochemical and Biophysical Research Communications, 271(3), 726-730.

Gane EJ, Stedman CA, Hyland RH, Ding X, Svarovskaia E, Symonds WT, Hindes RG, Berrey MM. 2013. Nucleotide polymerase inhibitor sofosbuvir plus ribavirin for hepatitis C. New England Journal of Medicine 368:34-44.

Geng J, Yuan P, Shao C, Yu SB, Zhou B, Zhou P, Chen XD. 2010. Bacterial melanin interacts with double-stranded DNA with high affinity and may inhibit cell metabolism in vivo. Archives of Microbiology 192(5): 321-329.

Gorr SU. 2009. Antimicrobial peptides of the oral cavity. Periodontology 2000 51:152-180.

Haig J. 1983. Porcellanidae (Decapoda, Anomura) from the Seychelles, Western Indian Ocean. Crustaceana 45:279-289.

Hartman LJ, Coyne SR, Norwood DA. 2005. Development of a novel internal positive control for Taqman based assays. Molecular and Cellular Probes 19:51-59.

Javle M, Curtin NJ. 2011. The potential for poly (ADP-ribose) polymerase inhibitors in cancer therapy. Therapeutic Advances in Medical Oncology 3:257-26.

Jensen PC, Purcell MK, Morado JF, Eckert GL. 2012. Development of a real-time PCR assay for detection of planktonic red king crab (Paralithodes camtschaticus (Tilesius 1815)) larvae. Journal of Shellfish Research 31:917-924.

Jin S, Lin XM, Law H, Kwek KY, Yeo GS, Ding C. 2012. Further improvement in quantifying 
male fetal DNA in maternal plasma. Clinical Chemistry, 58:465-468.

Kim W, Abele LG. 1990. Molecular phylogeny of selected decapod crustaceans based on 18s rRNA nucleotide sequences. Journal of Crustacean Biology 10:1-13.

Liu-Young G, Kozal MJ. 2008. Review: Hepatitis C protease and polymerase inhibitors in development. AIDS Patient Care and STDs 22:449-457.

Mättö J, Saarela M, Alaluusua S, Oja V, Jousimies-Somer H, Asikainen S. 1998. Detection of Porphyromonas gingivalis from saliva by PCR by using a simple sample-processing method. Journal of Clinical Microbiology 36:157-160.

Maurer JJ. 2011. Rapid detection and limitations of molecular techniques. Annual Review of Food Science and Technology 2:259-279.

McBeath AJ, Penston MJ, Snow M, Cook PF, Bricknell IR, Cunningham CO. 2006.

Development and application of real-time PCR for specific detection of Lepeophtheirus salmonis and Caligus elongatus larvae in Scottish plankton samples. Diseases of Aquatic Organisms 73:141-150.

McCartney AL. 2002. Application of molecular biological methods for studying probiotics and the gut flora. The British Journal of Nutrition 88(Suppl 1):S29-37.

McGaw IJ, Curtis DL. 2013. A review of gastric processing in decapod crustaceans. Journal of Comparative Physiology B, Biochemical, Systems, and Environmental Physiology $183: 443-465$.

Moorad JA, Mayer MS, Simovich MA. 1997. Extraction of DNA from anostracan cysts (Crustacea, Branchiopoda) for use in RAPD-PCR analyses. Hydrobiologia 359:159-162.

Morrison CL, Harvey AW, Lavery S, Tieu K, Huang Y, Cunningham CW. 2002. Mitochondrial gene rearrangements confirm the parallel evolution of the crab-like form. Proceedings of the Royal Society of London. Series B: Biological Sciences 269:345-350.

Ochert AS, Boulter AW, Birnbaum W, Johnson NW, Teo CG. 1994. Inhibitory effect of salivary 
fluids on PCR: potency and removal. Genome Research 3:365-368.

Okeke MI, Okoli AS, Nilssen Ø, Moens U, Tryland M, Bøhn T, Traavik T. 2014. Molecular characterization and phylogenetics of Fennoscandian cowpox virus isolates based on the p4c and atip genes. Virology Journal, 11:119.

Opel KL, Chung D, McCord BR. 2009. A study of PCR inhibition mechanisms using real time PCR. Journal of Forensic Sciences 55:25-33.

Otero-González AJ, Magalhães BS, Garcia-Villarino M, López-Abarrategui C, Sousa DA, Dias SC, Franco OL. 2010. Antimicrobial peptides from marine invertebrates as a new frontier for microbial infection control. The FASEB Journal 24:1320-1334.

Pan M, McBeath AJ, Hay SJ, Pierce GJ, Cunningham CO. 2008. Real-time PCR assay for detection and relative quantification of Liocarcinus depurator larvae from plankton samples. Marine Biology 153:859-870.

Paul R, Sankolli KN, Shenoy S. 1993. Juvenile morphology and appearance of sexual appendages in two porcellanid crabs, Petrolisthes rufescens (Heller, 1861) and Pisidia gordoni (Johnson, 1970) (Decapoda, Anomura, Porcellanidae). Crustaceana, 65:346-357.

Riisgård HU, Larsen PS. 2010. Particle-capture mechanisms in suspension-feeding invertebrates. Marine Ecology Progress Series 418:255-293.

Rådström P, Knutsson R, Wolffs P, Lövenklev M, Löfström C. 2004. Pre-PCR processing: strategies to generate PCR-compatible samples. Molecular Biotechnology 26(2):133-146.

Sánchez-Rodríguez A, Portal O, Rojas LE, Ocaña B, Mendoza M, Acosta M, Jiménez E, Höfte M. 2008. An efficient method for the extraction of high-quality fungal total RNA to study the Mycosphaerella fijiensis-Musa spp. interaction. Molecular Biotechnology 40:299-305.

Schrader C, Schielke A, Ellerbroek L, Johne R. 2012. PCR inhibitors-occurrence, properties and removal. Journal of Applied Microbiology 113:1014-1026.

Schneider S, Enkerli J, Widmer F. 2009. A generally applicable assay for the quantification of 

inhibitory effects on PCR. Journal of Microbiological Methods 78:351-353.

Siddiqui FA, Kazmi QB. 2003. A checklist of marine anomurans (Crustacea: Decapoda) of Pakistan, northern Arabian Sea. Memoirs of Museum Victoria 60:87-89.

Small HJ, Pagenkopp KM. 2011. Reservoirs and alternate hosts for pathogens of commercially important crustaceans: a review. Journal of Invertebrate Pathology 106:153-164.

Söderhäll K. 1982. Prophenoloxidase activating system and melanization - A recognition mechanism of arthropods? A Review. Developmental and Comparative Immunology 6:601-611.

Sritunyalucksana K, Söderhäll K. 2000. The proPO and clotting system in crustaceans. Aquaculture 191: 53-69.

Tincu JA, Taylor SW. 2004. Antimicrobial peptides from marine invertebrates. Antimicrobial Agents and Chemotherapy 48: 3645-3654.

Vadopalas B, Bouma JV, Jackels CR, Friedman CS. 2006. Application of real-time PCR for simultaneous identification and quantification of larval abalone. Journal of Experimental Marine Biology and Ecology 334:219-228.

Valdivia N, Stotz W. 2006. Feeding behavior of the porcellanid crab Allopetrolisthes spinifrons, symbiont of the sea anemone Phymactis papillosa. Journal of Crustacean Biology 26:308-315.

Vázquez L, Alpuche J, Maldonado G, Agundis C, Pereyra-Morales A, Zenteno E. 2009. Review: immunity mechanisms in crustaceans. Innate Immunity 15:179-188.

Wang SY, Hong C, Lotz JM. 1996. Development of a PCR procedure for the detection of Baculovirus penaei in shrimp. Diseases of Aquatic Organisms 25:123-131.

Watling L. 2013. Feeding and digestive system. In: Watling L, Thiel M, eds. The natural history of Crustacea, Vol 1, Functional morphology and diversity. New York: Oxford University Press, 237-260. 
533 Werding BERND, Hiller A. 2007. The Porcellanidae (Crustacea: Decapoda: Anomura) of the 534 Red Sea with description of a new species of Petrolisthes. Zootaxa, 1460:1-24.

535 Wiedbrauk DL, Werner JC, Drevon A M. 1995. Inhibition of PCR by aqueous and vitreous fluids. $536 \quad$ Journal of Clinical Microbiology 33:2643-2646.

537 Wilson IG. 1997. Inhibition and facilitation of nucleic acid amplification. Applied and $538 \quad$ Environmental Microbiology 63:3741-3751.

539 Yaqoob M. 1974. Larval development of Petrolisthes rufescens (Heller, 1861) (Decapoda, 540 Porcellanidae) under laboratory conditions. Pakistan Journal of Zoology 6:47-61.

541 Yoshii T, Tamura K, Taniguchi T, Akiyama K, Ishiyama I. 1993. Water-soluble eumelanin as a 542 PCR-inhibitor and a simple method for its removal. Nippon Hoigaku Zasshi 47:323-329. 543 Zasloff M. 2002. Antimicrobial peptides of multicellular organisms. Nature 415:389-395. 


\section{Table $\mathbf{1}$ (on next page)}

Yields of DNA from crab parts

DNA extracted (mean \pm 1SE) from different dissected parts of the porcelain crab Petrolisthes rufescens based on NanoDrop readings $(\mathrm{N}=6)$. 
Body part DNA concentration (ng/ $\mu \mathrm{l})$

$\begin{array}{ll}\text { Foregut } & 0.769 \pm 0.478 \\ \text { Midgut } & 1.919 \pm 1.541 \\ \text { Hindgut } & 0.487 \pm 0.140 \\ \text { Gills } & 1.073 \pm 0.704\end{array}$




\section{Figure 1}

DNA amplification at different concentrations in foreguts and fish extracts

Amplification products of $28 \mathrm{~s}$ primers from different Petrolisthes rufescens foreguts (FG) and fish muscle (see Materials and Methods). Extracted DNA aliquots were added to reactions at different amounts in order to assess potential inhibition due to DNA template concentrations. Undilutedforegut DNA masses in PCR reactions were 18.7ng (FG1), 4.1ng (FG2), and 0.93ng (FG3). From these, 50\% (0.5) and 25\% (0.25) dilutions were also tested. Fish DNA controls contained 1-5ng per PCR reaction.

\section{$1500 \mathrm{bp}$}

$500 \mathrm{bp}$ 


\section{Figure 2}

Effects of foregut extract on fish DNA amplification

Amplification of fish DNA using 28s primers in the presence or absence of foregut (FG)

extracts. Three concentrations of extracted foregut aliquots from three different crabs were added to the PCR reactions (initial undiluted reactions contained $2 \mathrm{ng}$ of crab foregut and $2 \mathrm{ng}$ of fish DNA extracts per reaction). The positive control contained only fish DNA for amplification and the negative control (to assess potential contamination with foreign DNA) contained no crab or fish DNA.

$1500 \mathrm{bp}$ $1000 \mathrm{bp}$ $700 \mathrm{bp}$ 500 bp

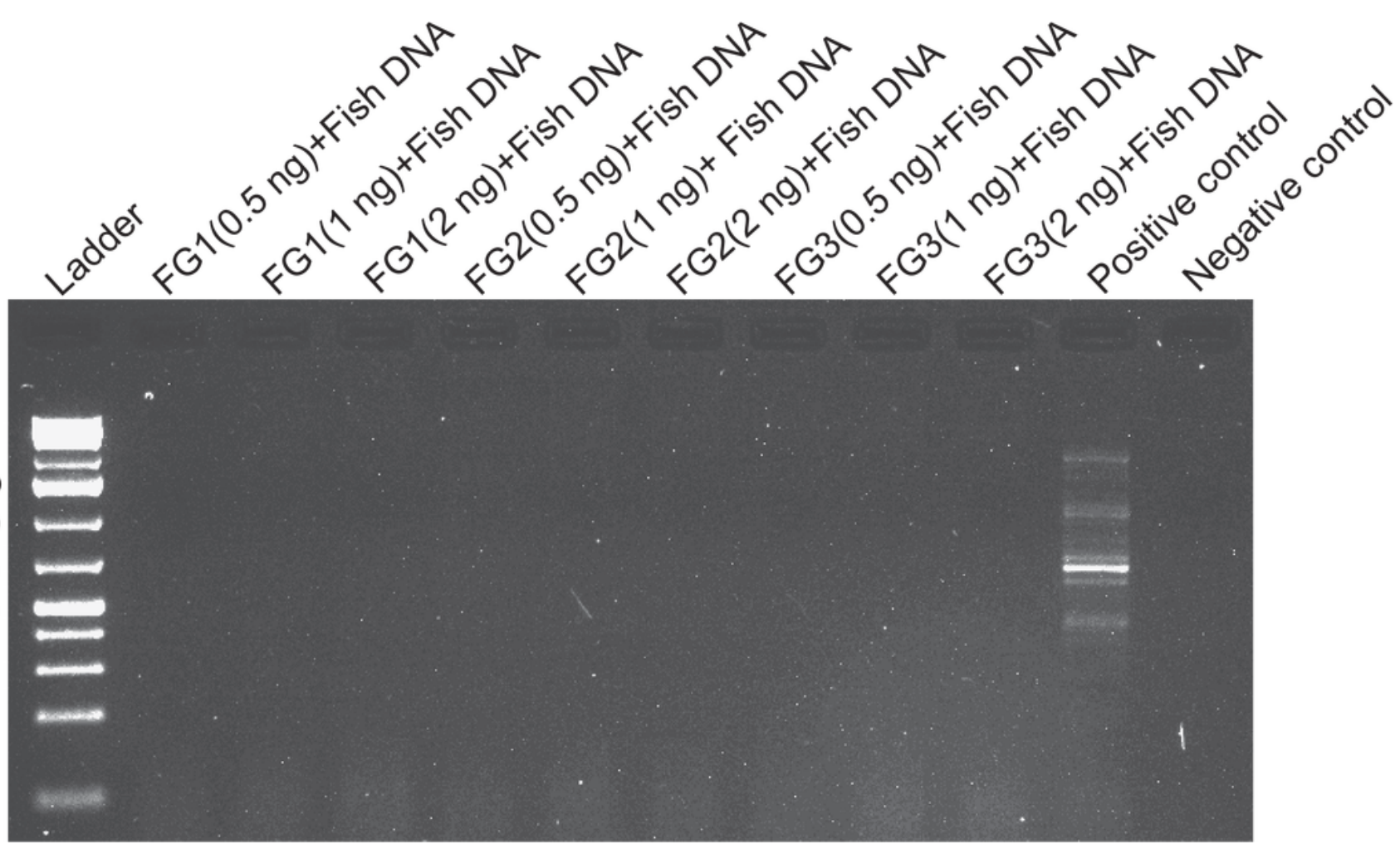




\section{Figure 3}

Foregut inhibition of $16 \mathrm{~s}$ amplification

Results of the amplification of bacterial DNA in crab tissues using universal 16s primers (see Methods). Samples from three different crabs were prepared to comprise either mixtures of midgut (MG), hindgut (HG) and gills (GL) together, or these three combined with foregut (FG) extracts from the same respective individual. The negative control assessed potential bacterial contamination and contained contained no crab or fish DNA. Empty lanes in the gel are not labeled.

$1500 \mathrm{bp}$ $1000 \mathrm{bp}$ $700 \mathrm{bp}$ $500 \mathrm{bp}$

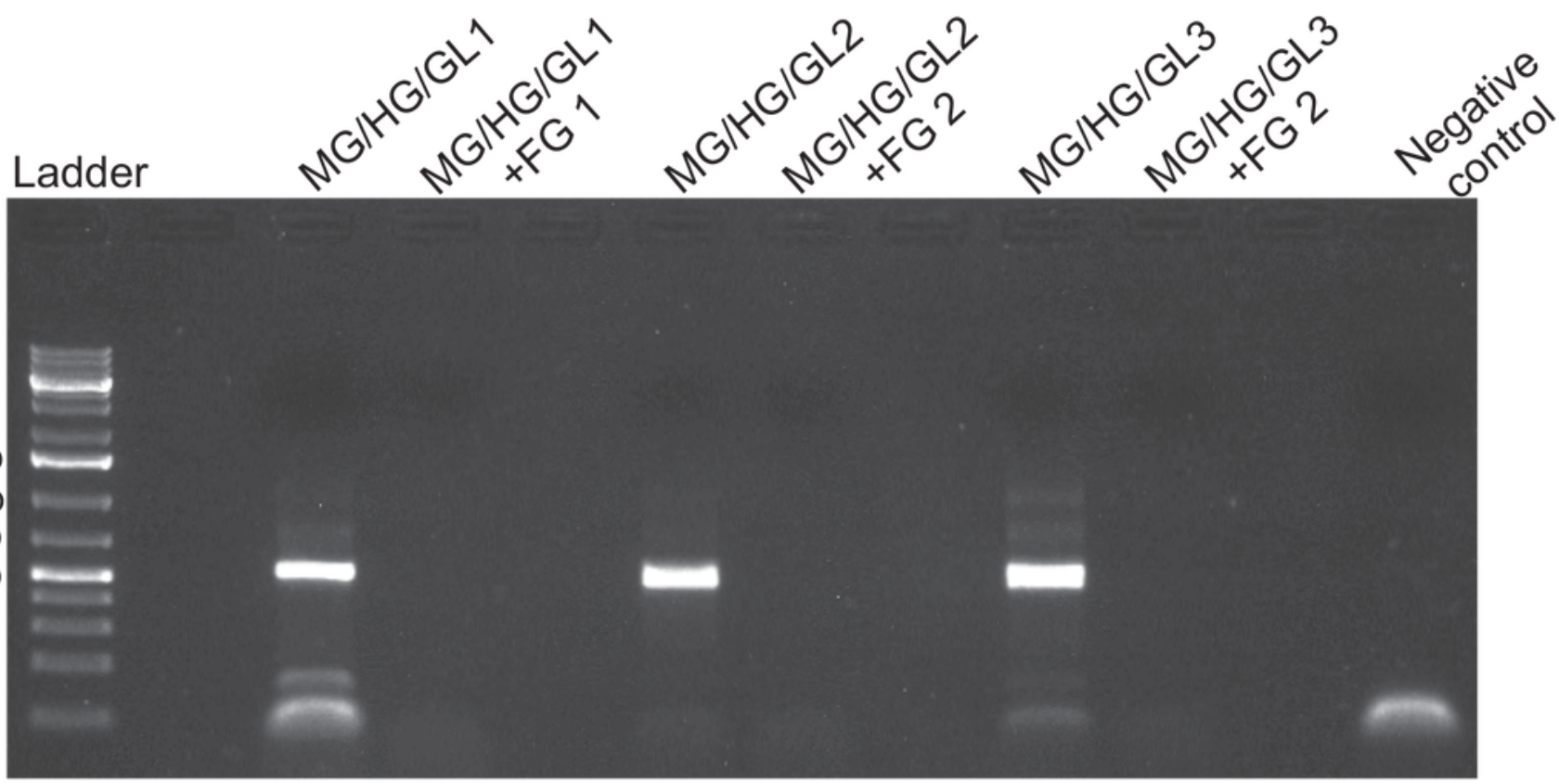




\section{Figure 4}

Activity limits of foregut inhibitor

Dilution experiment using $18 \mathrm{~s}$ primers to determine the activity limits of the inhibitor. The initial concentration of each foregut $(\mathrm{FG})$ extract $(\mathrm{N}=3)$ was serially diluted $\left(10^{-1}\right.$ to $\left.10^{-4}\right)$ for a total of five test concentrations per crab foregut. One empty lane (next to the ladder) is

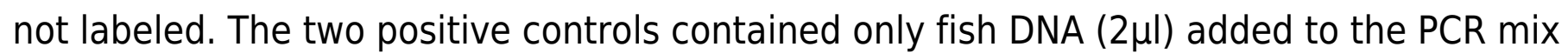
and no DNA was added to the negative control to assess potential contamination of the reaction mix.

$3000 \mathrm{bp}$ $2000 \mathrm{bp}$ $1500 \mathrm{bp}$
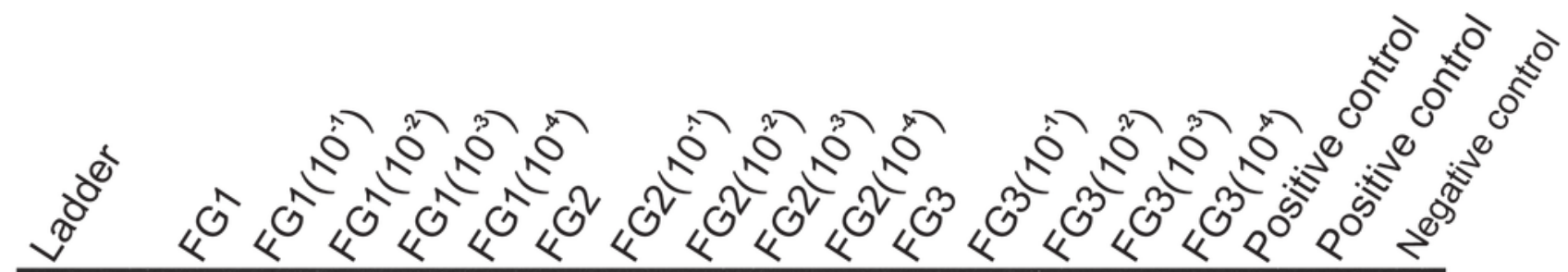

$500 \mathrm{bp}$

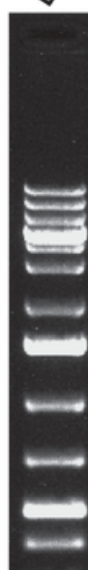
ए
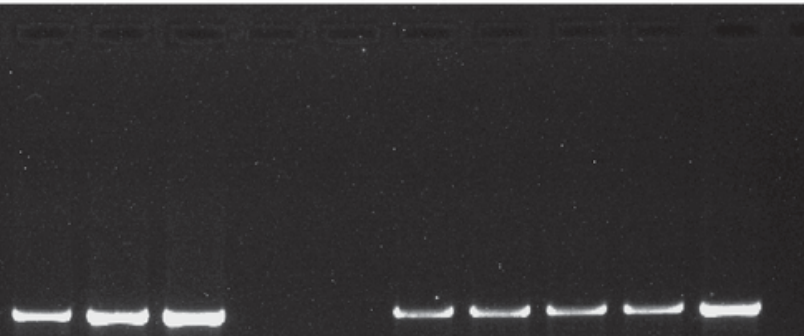


\section{Figure 5}

Midgut degradation of inhibitor

Amplification of 18s sequences from fish in the presence of foregut (FG) extracts and FG mixed with midgut $(M G)$ suspensions from the same individuals $(N=3)$. Bands of PCR product indicate the neutralization of the foregut inhibitor. Positive and negative controls are as in Fig 4. Empty lanes are not labeled.

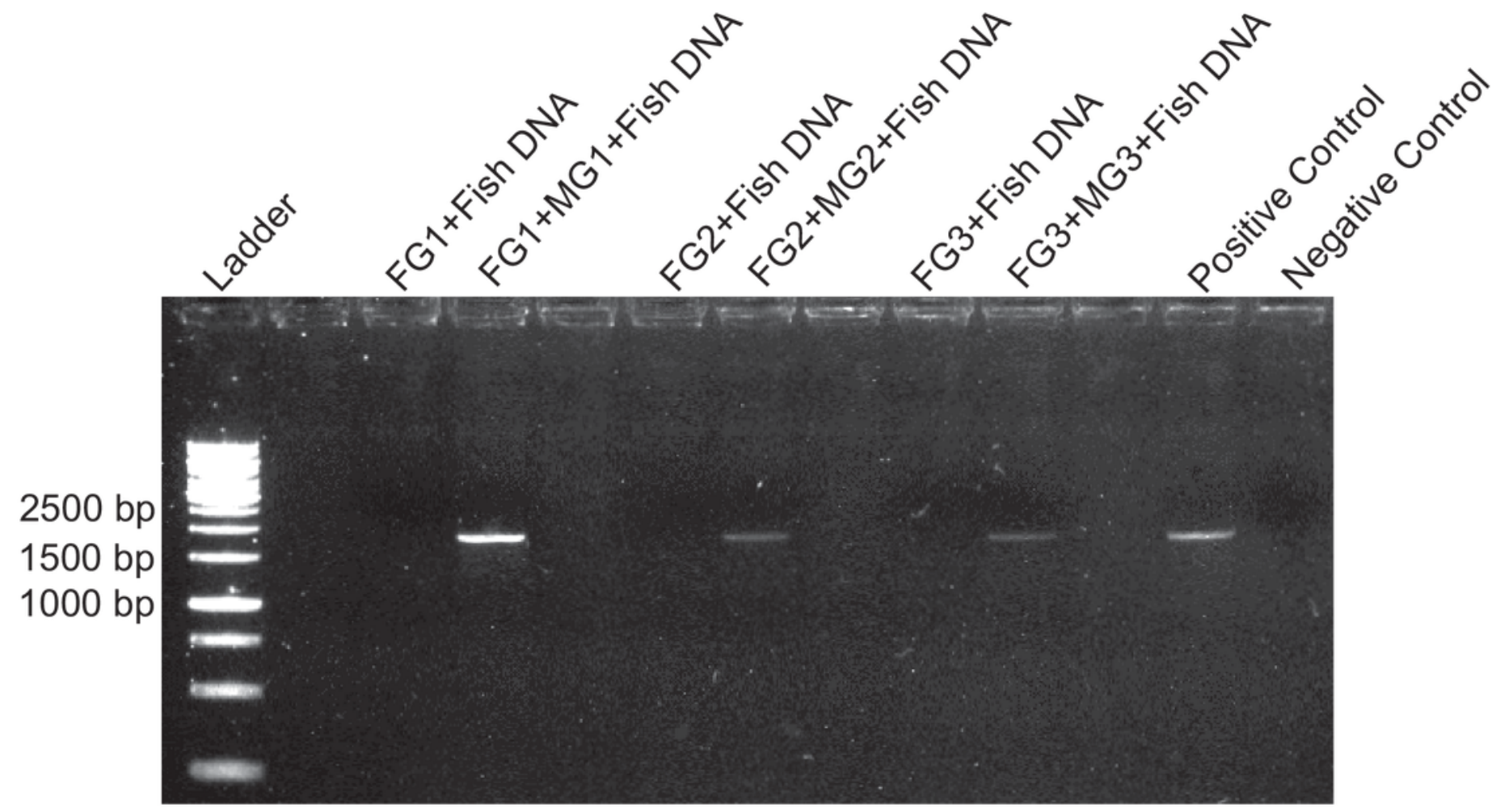




\section{Figure 6}

Dilution of midgut aliquots and foregut inhibition of PCR

Tests of the activity limits of midgut (MG) suspensions to counteract the foregut (FG) PCR inhibitor $(\mathrm{N}=3)$. Fish DNA ( $3 \mu \mathrm{l})$ was mixed with FG extracts and one of five concentrations of MG extract (baseline concentration to $10^{-4}$ ) from the same crab before amplifying with $18 \mathrm{~s}$ primers. Presence of PCR product indicates the neutralization of the inhibitor. Positive and negative controls are as in Fig 4. Empty lanes are not labeled. Though not completely clear from the picture, a very faint band, denoting amplification, was observed for FG3+MG3(10 ${ }^{-4}$ ) .

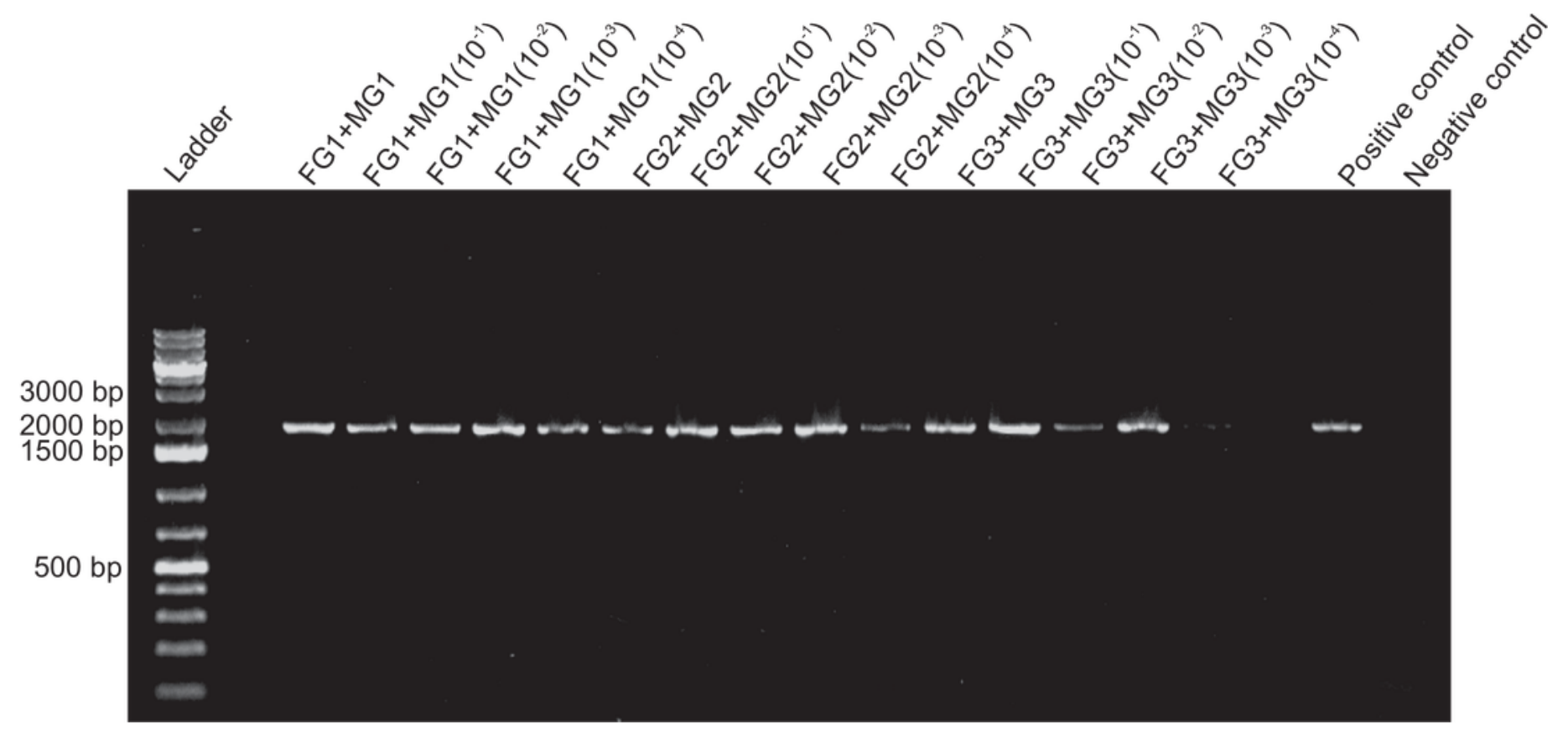




\section{Figure 7}

Effect of boiling on foreguts

Effects of heating foregut $(\mathrm{FG})$ extracts $\left(99^{\circ} \mathrm{C}, \mathrm{hr}\right)$ to assess the stability of the inhibitor.

Three different foreguts were boiled and added to fish DNA before amplifying with 18s

primers. Empty lanes are not labeled. Labeled lanes without bands indicate inhibition of PCR.

Positive and negative controls are as in Fig 4.

$3000 \mathrm{bp}$

$2000 \mathrm{bp}$

$1500 \mathrm{bp}$

$500 \mathrm{bp}$
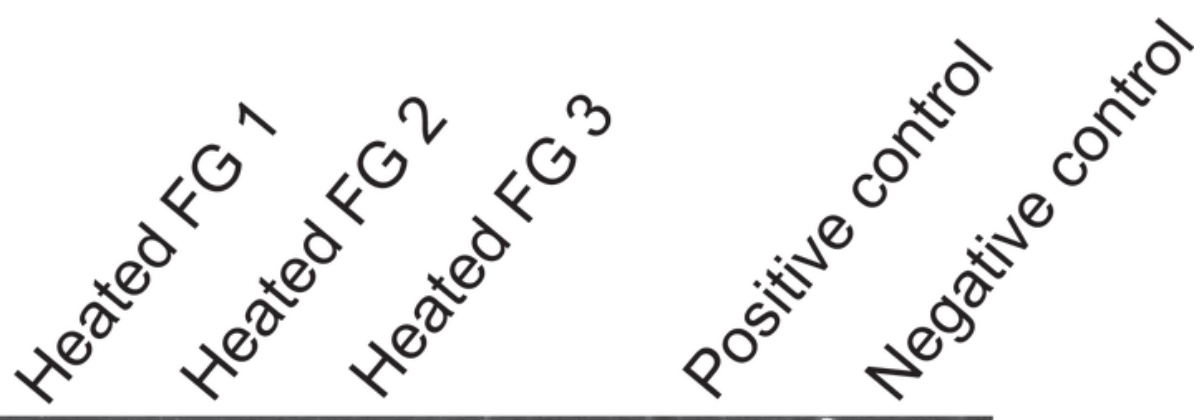
Figure 8

Relative melanin content of samples

Absorbance of samples at $320 \mathrm{~nm}$ to assess melanin content $(\mathrm{N}=4)$. Bars represent means + 1SE. Statistical analysis was performed with one-way ANOVA. 


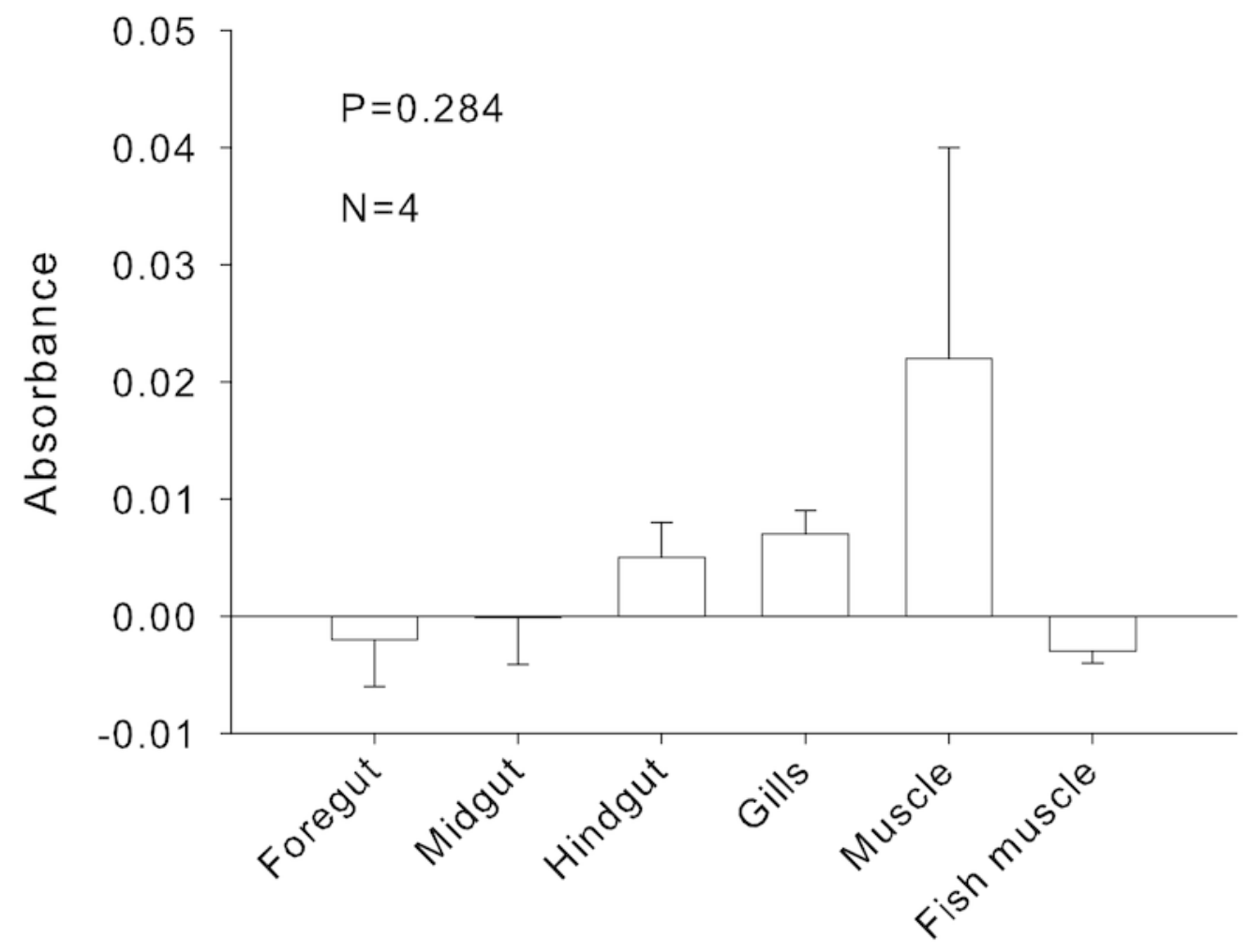

